\title{
O PROVOCARE STILISTICĂ ÎNTR-UN ROMAN REINVENTAT: „MOARTEA CARE VINE, PLEACĂ ŞI IAR VINE” DE VIRGIL TĂNASE
}

\section{„Vă pierdeți vremea. \\ Citind această carte vă pierdeți vremea.}

Ceea ce nu e poate de lepădat în sensul în care, în civilizațiile noastre mediteraneene, de sorgintă greacă și latină, dar întrucâtva turcite, se spune cu dreptate că omul care muncește pierde un timp prețios. Puteți fi liniștiți. Citind această carte vă pierdeți vremea și cum nu vi se cere nici un efort, fie chiar și numai de gândire, puteți fi siguri că ați tras chiulul celor care, după ce-au citit în Engels despre cum prin muncă maimuța devine om, vor acum să facă din dumneavoastră furnică punându-vă să trageți în jug ca boul. Punct de vedere pe care nu-l împărtășesc. Așa încât, ca să nu vă bateți capul căutând vreun înțeles, e bine să știți

de la bun început că nici din acest punct de vedere n-aveți a vă face griji : nu e nimic de priceput. Literatura nu e făcută ca să vă dea indicații utile după tipicul cărților de bucate și al romanelor realiste, ai căror autori vor să vă lumineze și să vă îndrume. În ceea ce mă privește am convingerea că dacă nu v-a luminat Dumnezeu, ar fi ridicol să-ncerc s-o fac eu ! " [1]

Moartea care vine, pleacă şi iar vine este o proză de structură şi vibrație intelectuală, pentru care lucrurile reprezentate nu sunt suficiente în sine, trimițând la o realitate care vrea să sugereze mai mult. În cuprinsul lui, amănuntul realist, invenția fantastică, divagația onirică sau reversul lor, uneori absurde, devin modalități ale simbolului. Și scriitorul nu se oprește aici. Încă de la început, adică în "Nota pentru ediția în limba română” care deschide cartea, Tănase apelează la o strategie discursivă ironică. Scopul este de fapt să ne incite la lectură. De altfel, „consecvent cu vocația sa și în termenii convenției literare romanești, scriitorul Virgil Tănase propune un pact alternativ de lectură pe care cititorul este liber să-l semneze sau nu". [2] Căci o asemenea proză, în care jocul de cuvinte poetice şi simbolice ambiguizează totul, nu poate exista fără participarea cititorului, pe care îl solicită în grad înalt, îl formează şi îl deformează.

„E bine, e cinstit să se ştie din capul locului că romanul meu (dacă pot să-i spun aşa!) nu e pentru cei care vor să fie mai buni (sau mai răi, nu contează), mai deştepți, mai învățați..., etc. Aceştia trebuie să caute romanele de şcoală, manualele pe care le scriu Domnii învățați, care ştiu ce-i aia binele şi ce-i aia 
răul, care ştiu să facă adunări, scăderi, înmulțiri şi ştiu cu ce se mănîncă pătratul ipotenuzei pentru ca-n România să fie bine şi tot românul să prospere. [...]Cartea mea e pentru cei care văd în literatură un îndemn să se joace de-a hoții şi vardiştii nu cu făpturile de piatră ale lumii, ci cu înjghebările mult mai sprințare ale literaturii. " [3]

Virgil Tănase are harul unei desăvârşite măiestrii inventive, reuşind de fiecare dată să ne convingă că născocirile sale cele mai extravagante sunt cât se poate de logice şi chiar fireşti. Moartea şi cadavrul unei interimare- $\hat{\imath}$ şiruire de viziuni onirice din care nu se ințelege chiar nimic, dar al cărui rost e să dea o idee despre atmosfera generală în care se desfăşoară balul la care sunteți invitați, oferindu-vi-se ocazia să dansați tango în fața unei oglinzi cu virtuți epurative. [4] Subintitulat "roman jandarm”, cartea, construită după cum ne-am obișnuit după un tipar arhitectural aparte, poetică şi tulburătoare totodată, care se înalță prin varietatea procedeelor stilistice, impresionează prin cele cincisprezece caiete, ordonate calculat, tocmai pentru a-l stârni pe cititor să descopere dacă există o fuziune între spațiul ficțional şi cel real. Interimara, moartă sau nu, angajată a serviciului de spionaj, declanșează vârtejul oniric. Se pare că aceasta nu are o altă soluţie decât să-şi schimbe identitatea pentru a supravieții:

„Dusă de vârtejul unui destin hain, văduva acceptă, fără să știe despre ce e vorba, să slujească în armată pe postul de interimară. Devine, clandestin, mamă. Nu consider potrivit să dezvălui cum și în ce fel, această femeie pe care mulți au socotit-o victima unui detracat, ucisă într-un tren de noapte de un salariat al căilor ferate, a ajuns să conducă, mai târziu, o țară a cărei voce s-a făcut, în fine, auzită în concertul națiunilor. [...]În ceea ce mă privește, mi-am slujit patria cu cinste și, când s-a putut, chiar cu onor. " [5]

Personajul anonim, interimara, pare a fi proiecția spectaculoasă a scriitorului însuşi, veşnic inadaptat sistemului din care face parte, un solitar pornit în căutarea sinelui, un înstrăinat, un călător singuratic, [6] care îşi găseşte refugiul în artă. Romancierul, un bun cunoscător al tehnicilor epice moderne şi postmoderne, ne propune un fel de „ambiguitate creatoare împletită cu o continuă suspiciune atât față de personaj, cât şi față de naratorul care îi dă viață". [7]

„Provocarea romanului lui Virgil Tănase este una stilistică şi compozițională: el reuşeşte să păstreze convențiile unei literaturi agreabile, accesibile, dar mai ales să le deturneze într-un experiment livresc. Fraza este una arborescentă, amplă, voit confuză, cu totul nepotrivită pentru un roman de aventuri sau unul polițist, registrul e cel mai adesea ludic, ironic, intrând în contrast cu gravitatea evenimentelor care se derulează. " [8] 
Există o aspirație spre idealitate, spre frumusețe, puritate, plinătate sufletească, dar care este înăbuşită, sufocată de existență. La limită, imaginea femeii devine metaforă a propriei identități, o biografie fantasmatică a relației de dragoste dintre autorul bine integrat diasporei şi arta sa eliberatoare.

Personajele lui Virgil Tănase par a se strecura intempestiv în decorul epic sau dramatic, polemizează, apoi dispar la fel cum au venit. Asistăm hipnotizați la deschiderea unei literaturi labirintice, analoagă unei realități. $\mathrm{Cu}$ o ingeniozitate atipică, Virgil Tănase îşi concepe scrierile „strategic“, cu rigoare, asemenea unor compoziții muzicale complexe, cu laitmotive ce interferează.

„Din aceste jocuri stilistice și de oglinzi mustește o profundă lehamite de viață, o anxietate existențială pe care umorul debordant al autorului o face suportabilă, un umor strainiu pentru că-n spatele lui se simte o nesfârșită disperare. " (Edgar Reichmann, Le Monde) [9]

Virgil Tănase face literatură din orice. Își ia inspirația din ce-i cade la mână. Malaxează, frământă și realul devine cu totul altceva decât am crezut că este. Văruiește cu vopsele delirante decorul searbăd al vieții noastre de zi cu zi.(Michèle Gazier, Télérama)

Despre Virgil Tănase putem afirma cu certitudine că se numără printre scriitorii români bine integrați în spiritul exilului, care subzistă cu fermitate încercărilor vieții prin atitudine, prin transparență, luciditate şi meticulozitate tipic românească. El este omul care trăieşte prin arta sa, uimeşte prin puterea de a prezenta viața în complexitatea ei socială şi psihologică, şi mai ales, ne fascinează prin poeticitatea scrisului său.

\section{NOTE:}

[1]. Virgil Tănase, Moartea care vine, pleacă şi iar vine, Editura Muzeul Literaturii Române, București, 2017, p.7.

[2]. Andrei Grigor, Glosa, Mitul lui Sisif și Omul revoltat al lui Virgil Tănase. Caiete critice, Nr. 10 ( 2) / 2013, p.49: http://caietecritice.fnsa.ro/wordpress/wpcontent/uploads/2013/06/CC-10-2013.pdf

[3]. George Motroc, „Literatura e cea care ne dă ocazia să înțelegem ce putere dumnezeiască e în noi" - dialog cu scriitorul Virgil TĂNASE. Convorbiri literare, REVISTĂ A UNIUNII SCRIITORILORDIN ROMÂNIA, Anul CL, Mai , 2018.

http://convorbiri-literare.ro/?p=9550

[4]. Virgil Tănase, op. cit., p.11.

[5]. Ibidem, p.418

[6]. Virgil Tanase : le promeneur solitaire. Combats Magazine, 18 octobre 2004.

[7]. Patrice Bollon, Un latin balcanic. Caiete Critice. Revistă editată de Fundația Națională pentru Ştiință şi Artă, Nr. 1(207), 2005, p. 20. 
[8]. Bogdan Crețu, Moartea care vine, pleacă şi iar vine. Ziarul de Iași, ianuarie, 2018. https://www.ziaruldeiasi.ro/stiri/moartea-care-vine-pleaca-si-iar-vine-180512.html)

[9]. Reichmann, Edgar, Les morts ludiques de Virgil Tănase. Le Monde, 22 iunie 1984.

\section{BIBLIOGRAFIE:}

Antofi Simona, GENERAL DICTIONARY OF ROMANIAN LITERATURE OBVERSE AND REVERSE CRITICAL RECEPTION, în Oana Cenac (coord., edit.), International Conference of Common Vocabulary/Specialized Vocabulary: Manifestations of Creativity of Human Language, 6-7 iunie 2014, publicate în volumul MANIFESTARI ALE CREATIVITATII LIMBAJULUI UMAN, 2014, p. 13-19, Accession Number WOS:000378446400001.

Bollon, P., Un latin balcani. Caiete Critice, Revistă editată de Fundația Națională pentru Ştiință şi Artă, Nr. 1(207), 2005.

Cenac Oana, General aspects of current political terminology, în Lexic politic - discurs politic, 2014, p.124-130, ISBN:978-606-17-0633-4, WOS: 000378358200007.

Crețu, Bogdan, Moartea care vine, pleacă şi iar vine. Ziarul de Iași, ianuarie, 2018.

Grigor, A., Glosa, Mitul lui Sisif și Omul revoltat al lui Virgil Tănase. Caiete critice, Nr. 10 ( 2) / 2013.

Ifrim, Nicoleta, History and Identity in Post-Totalitarian Memoir Writing in Romanian, CLCWeb: Comparative Literature and Culture (ISSN 1481-4374) http://docs.lib.purdue.edu/clcweb/, nr. 16.1 / March 2014, Purdue University Press, revistă indexată ISI Art and Humanities Citation Index http://docs.lib.purdue.edu/clcweb/vol16/iss1/11/, Accession Number WOS:000333326200011.

Motroc, G, „Literatura e cea care ne dă ocazia să înțelegem ce putere dumnezeiască e în noi” dialog cu scriitorul Virgil TĂNASE. Convorbiri literare, REVISTĂ A UNIUNII SCRIITORILOR DIN ROMÂNIA, Anul CL, Mai, 2018.

Reichmann, E., Les morts ludiques de Virgil Tănase. Le Monde, 22 iunie 1984.

Tănase, V., Cette mort qui va et vient et revient, roman gendarme, Ed Hachette, Paris, 1984.

Tănase, V., Moartea care vine, pleacă şi iar vine, Editura Muzeul Literaturii Române, București, 2017.

Virgil Tanase : le promeneur solitaire. Combats Magazine, 18 octobre 2004. 


\title{
A Stylistic Approach in a Renewed Novel: Moartea care vine, pleacă şi iar vine by Virgil Tănase
}

\begin{abstract}
Virgil Tănase makes his debut as a novelist and playwright in a foreign country, in another language which, at first, his inner self does not feel too close: „To live a writer's life, anywhere near authenticity, I had - mind you - to 'carve out' my works in a language different from the one I learnt at home".

The personalised language of the writing is more often than not dominated by a poetical and metaphorical sense which obturates the reader's access to the natural course of the writing for a few moments. But Virgil Tănase, with his keen spirit, with his perfect directorial sensibility, mastering the modern and postmodern epic techniques, concocts apparently illogical puns and later on, at the end of the narrative maze, one discovers an open, transparent and lucid writing, with a lively and chameleonic style responsible here and there of the reader's perplexity.
\end{abstract}

Key-words: literature, metaphorical symbols, identity. 